
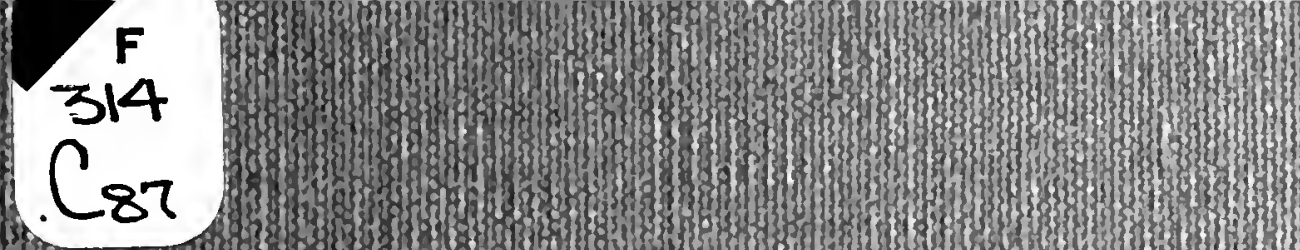

\title{
.
}

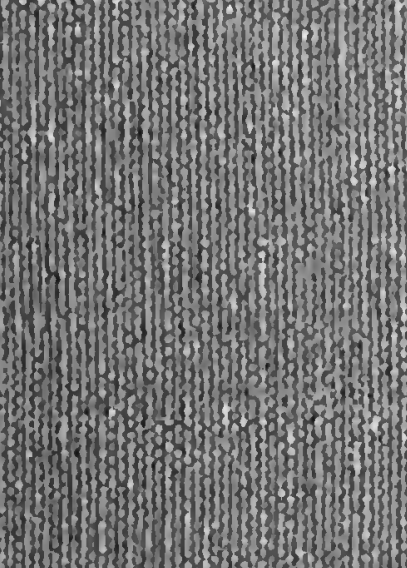

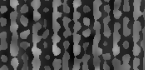









\title{
THE PAN-AMERICAN POLICY OF JEFFERSON AND WILKINSON
}

\author{
BY \\ ISAAC JOSLIN COX
}

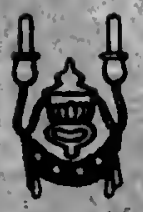

Reprinted from the Mississipt

Valley "Historiola" Review

Vol. I, Septeñber, 1914 


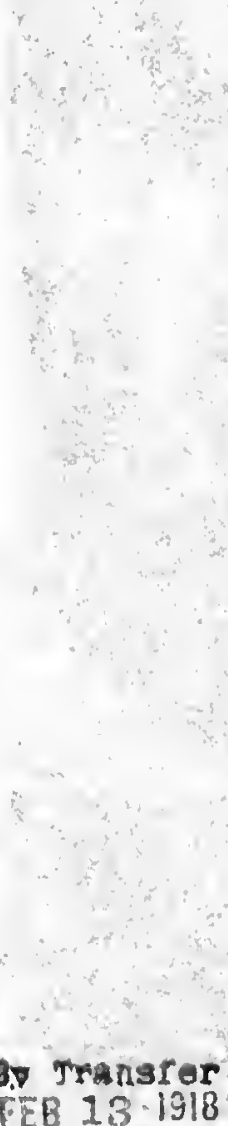

$$
\begin{array}{r}
F 314 \\
087
\end{array}
$$

FEB 13 - 1918

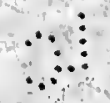


THE PAN=AMERICAN POLICY OF JEFFERSON AND WILKINSON 


\section{THE PAN-AMERICAN POLICY OF JEFFERSON AND WILKINSON}

The desire of President Jefferson to gain the Floridas profomdly influeneed his whole attitude towards Napoleon Bonaparte. Early in 1808 this led the emperor to hint that with proper subservicney in regard to past eommercial exaetions and a future alliance against England the Ameriean executive might obtain his long-cherished desire. Armstrong, our minister to France, did not fancy the purpose that secmed to animate the Freneh emperor nor the language in which he expressed it, and advised his government to declare war against either Franee or England, but in either case to seize the Floridas at once. Jefferson and Marlison did indeed publish Napoleon's imperions demand; but at the same time they assumed a mild tone in their instructions to Armstrong that little eomported with vigorons aetion. They likewise instrueted him to assure the imperious antoerat that they "had chosen as the basis for their poliey a fair and sincere neutrality among the eontending Powers," and were unwilling to abandon it "for the purpose of obtaining a separate and particular object, howerer interesting to them." Yet they might be led by British hostility to preoceupy this territory, and in that ease wonld be pleased to know that "the measure [had] received His Majesty's approbation.", .

Napoleon made his proposal just as he was about to orerthrow the Bourbon power in Spain, for the evident purpose of persuading the United States to comtenance his later plans in regard to Spanish-America; but lis threat and its accompanying bribe proved equally ineffectual. As Madison wrote Armstrong, Great Britain had views upon Spanish-America as well as Napoleon, and was equally interested in the neutrality of the United States. The latter nation eould easily stir up a revolution in Spanish-Ameriea, but wonld not do so if well treated by both belligerents. Upon being informed of this assumption of

1 Henry Adams, History of the United States (New York, 1859-1891), 4:993, 306. 
neutrality the emperor nublnshingly denied the bribe that his muthless despoiling of Spain had seemed to make possible."

The famous "Dos de Maio" in Madrid presented to Jefferson another opportunity to realize his wish. That memorable uprising of the Spanish people against their oppressors did not, it is true, greatly arouse Jeffer'son's sympathy. His "pursuit of Florida," to quote Henry Adams, had enmeshed him too completely for that. Rather, while Bonaparte was oceupied with Spain, he anticipated that England would make up with the United States. Then withont committing himself to either of the principal contestants he expected to seize West Florida as far as the Perdido as a rightfinl possession and "the residue of the Floriclas" as a reprisal for the spoliations that for years he had vainly urged France and Spain to acknowledge. Thus his policy was an exceedingly selfish one. In earrying it out he proposed to gather his new recruits and armed vessels at points where they would be ready to act, the moment Congress authorized the blow. He thought he already had a sufficient force near Baton Rouge to attend to that post and he must now prepare for the seizure of Mobile, Pensacola, and St. Augustine. The embargo afforded the necessary pretext for massing troops on the St. Mary's and the Tombigbee. ${ }^{3}$

Early in September Gallatin warned him from New York that, despite the tone of the Washington papers, there was a general feeling in favor of the Spanish patriots. ${ }^{*}$ Yet the president did not abandon his quest for the Floridas, but affected to be puzzled by Armstrong's earlier arlvice to seize them at once. The tidings of the victories over the French at Bailén and Vimeiro rendered Napoleon less formidable but inereased the possibility that England might become the protector of the threatened Spanish colonies. It was with this in mind that the president recorded the determination of the cabinet after its meeting of October 22: "Unanimonsly agreed in the sentiments which should be mauthoritatively expressed by our agents to influential persons in Cuba and Mexico, to-wit: "If you remain under the dominion of the kingdom and family of Spain, we are con-

2 Adams, History of the United States, $4: 311$.

3 Thomas Jefferson, Writings (Ford ed. - New York, 1892-1899), 9:203.

4 Jefferson Papers, ser. 3, vol. 7:71. 
tented; but wo should be extremely mwilling to see you pass under the dominion or ascendeney of France or England. In the latter case, should you choose to declare independence, we cannot now commit onrselves by saying we would make common canse with yon, but must reserve onrselves to act according to the then existing eiremustances; but in our proceedings we shall be influeneed by friendship to you, by a firm feeling that our interests are intimately connected, and by the strongest repugnance to see you under subordination to either France or Englant either politically or commercially.', , 5

It was in kerping with this decision that the president, a week later, answered a communication of William C. C. Claiborne, who as grovernor of orleans Territory was in a favorable position to know the sentiments of neighboring Spanish offieials. Clai-. borne had sent lim a Spanish paper that savagely attacked the Ameriean policy. In part the president replied: "The truth is that the patriots of Spain have no warmer friends than the Administration of the United States, but it is our duty to say nothing for or against citler [faction]." After expressing the opinion of the eabinet in regard to Cuba and Mexico, he adderl: "We consider" their interests and ours as the same, and that the object of both must be to exchde all Emropean influence from this hemisphere." The governor was instrueted to express this sentiment to any proper characters from either provinee and partieularly to inform them that the American anthorities lad "nothing more at heart than their friendship." .

Despite the protest one feels that the Floridas still playerl an important part in Jefierson's professed friendship for Spain or her colonies. The contemporary Spanish officials on the imperiled frontier contimued to think so and there was much in Jefferson's snbsequent utteranees and deeds to justify them. In none does this appear so elearly as in his selection of the envoy to convey his new message of friendliness. His choice fell on General James Wilkinson, a former diseradited Spanish pensioner. In this task Wilkinson, the agent, was as thoroughly influeneed by personal motives as was . Jefferson by the prospeet of immediate national gain.

5 Adams, History of the Unitcd States, $4: 340$.

Ghomas Jefferson, Writings (Iemorial ed. - Washington, 1903-1904), 12:186. 
Wilkinson's first reference to this propaganda occurs in lis lotter of March 12, 1807 , althongh in this lie mentioned Jefferson's earlier desire to ocenpy Cuba. In his view the United States and Great Britain shonld combine to preserve the western world from Napoleon and his unwilling ally, the king of Spain. With the aid of the British fleet they conld preserve their own territory, occupy Cuba, reduce the Floridas, and give independ(nice to Mexico. ${ }^{7}$ He evidently made this suggestion to conceal from his superior the true character of Walter Burling's mission to Mexico City and to induce the president to pay for it. Later in the same month he snggested that an alliance composed of the independent states of Mexico, Peru, and Cuba might, with the aid of the United States, bid defiance to the Old World.

It is possible to infer that Wilkinson's references to an Ameriean alliance were inspired by a desire to neutralize in the mind of the executive the storm of protest that his arbitrary eareer in New Orleans had aronsed. If so, it proved largely ineffective. $\Lambda$ like result followed his proposal for common action with Great Britain. The Chesapeake affair destroyed such a possibility. For a time it was donbtful if his vulnerable reputation conld withstand the public execration aronsed by the Burr trial, the congressional attacks urged on by John Randolpl, and the inrestigation by a military court of inquiry. But in betraying Burr he had gained the support, if not the confidence of Jefferson, while his Spanish intermediary, Governor Vizente Folch of West Florida, almost perjured himself in his behalf. ${ }^{\text {. Thus he }}$ prospered far beyond his deserts, and resplendent in a coat of official whitewash, next appeared before his former Spanish paymasters, as the harbinger of a new day of freedom.

It is difficult to determine why Jefferson selected Wilkinson for this role. The general's own advocacy may have influenced lim, but it is more likely that he also hoped to make the other break with his former Spanish accomplices. Very likely he doubted if Wilkinson had disproved the charges of corrupt dealings with the Spaniards. But the narrow eseape from convic-

T Wilkinson to Jefferson, March 12, 1907. Papers Relative to Burr's Conspiracy, manuseript in bureau of rolls and library, department of state.

s Feport of the Committee Appointed to Inquire into the Conduct of General Trillinson, February 96, 1811 (Washington, 1811), 42-50. Ezekiel Bacon was chairman of the committee. 
tion must have aroused feclings of repentance in his subordinate. By sending him on a mission that would be distasteful to his former bibers, the president might effectually lemove him from further temptation of this sort. At the same time Wilkinson conld serve as well as another to warn the Spanish colonial officials not to cultivate close commercial or political relations with Great Britain, and to proffer the friendly aid of the United states.

About a year after he had proposed that Great Britain and the United States should mite in favor of a New World policy, Wilkinson warned José Vidal, the Spanish vice consul at New Orleans, arainst the machinations of the former power. He announced the accession of Feldinand VII to the throne of Spain and the presence of a French agent on the Mexican border. IIe then inforned the otler that the British offecials were also planning a series of intrigues in the Spanish colonies, and resired the United States to make common cause with them. Should the latter refuse to coopperate they would carly on their propaganda alone, and would probably inchude in it an attack on the Floridas and even New Orleans." This possibility, together with the rumor that Burr was reviving his project, was sufficient to justify Wilkinson's warning. One suspects, however, that he may have designed it to assist the application that he had just marle to Folch for an exculpatory letter to be used before the court of inquiry.

After this tribunal rembereal its favorable but muleserved verdict, Wilkinson largely ceased to play the part of suppliant with his Spanish correspondents. In his letter to Governor Folch, August 25, 1808, he wrote that Spain was bound to fall under the control of Bonaparte. The Spanish colonies might then declane their independence under a new dynasty, with a now order of nobility in which Folch ought to have an important station. If talent for intrigue was a requirement, Folch certainly could meet it. The new nation would then have to decide whetler to seek European or American alliance. At any rate. as he nred three weeks later, the Spanish colonies must dlefent

Inelosure in letter of Vidal to Iturigaray, April 7 , 1808. Marina, 1909 a 1814. Archivo Geveral y Publico de la Nación, Mexico. H. E. Bolton. Guide to Matrrials for the History of the Cnited States in the Principal Archires of Merico (Washington, $1913), 183$. 
themselves. The British could nerel prevent Spain from suecumbing to Bonaparte, although they were extending their influenee throughout her colonies wherever possible, and planning to eontrol the whole of them. For the present Napoleon was paying no attention to this phase of the contest, but in the eourse of two vears he would foree England to make peaee, eeding Spanish-America to him. Thhen this region inevitably yielded itself, the concueror would vigorously proseribe his enemies. So Wilkinson adrised Folch to delay assmming sides. "In the meantime," he added, "save your province from any European power and let Somernelos take care of Cuba, which may slip into the hands of a false frient." "To relieve his suggestion of selfishmess he added: "My country must undoubtedly sympathize with Spanish-America and if ealled on will help her." ${ }_{10}$

In this warning about West Florida and Cuba Wilkinson had Jefferson's policy in mind. To his patron he now wrote in regard to the other project, expressing the "liveliest hopes" in the speedy emaneipation of Mexico and South America. Possibly his hopes were lively because of his expressed desire to partieipate in this "glorious achievement." 11 He emphasized the desirability and necessity of an "excision of our transatlantie connections" by which "we should eseape the allurements of inordinate wealth and the poisons of huxurious indulgenee," and asserted: "Omr accuaintance with the Enropean World would gradnally subside, fleets and Armies wonld insensibly beeome useless to a People of self movermment; and a persevering respeet for aneient liabits, and a fine adherenee to principle, would perpetuate the freedon and happiness of the people of United Ameriea, to endless time." With this in mind he mentioned the eredulity with which the "feeble uninformed Spaniards" were "surrendering themselves to the interested, officions interfer-

\footnotetext{
10 Inclosures in letter of Foleh to Someruelos. Reservado No. 130, Papeles Procedentes de la Isla de Cuba, Legrijo 1566, Archivo General de Indies, Seville. This source will be referred to as "Cuban Pajers." The same material is fond in Estado, Legajo 5550, Arehivo Historico National, Marlril.

This correspondence was transmitterl through Calyain W. I'. Gaines at Fort Stoddert, whose suspicions were so thoroughly aroused, desplite his friendship for Wilkinson, that he male the matter the subject of a personal letter to Jefferson, Jamury 25,1809 .
}

11 Wilkinson to Jefferson, Oetober 1, 1808. Tefferson Papers, ser. 2, vol, 85:109. 
"Hee of the British" from which spanish-America was not likely to be exempt. II felt that agents should be sent to warn the Mexican anthoritios against these "iusidious eneroachments" and assure them of American sympathy and offered to convey this messagre to the Marques de Somormelos, whom le knew persomally. The manoucs was "extrenely feminine in his exterior, and of ferble intelfact" and "withont some seasonable counteraction on onr part" the British night "cajole or frighten him" out of Cuba and the Floridas.

Wilkinson relaromel to the sentiments that the Mexicans had allealy expessul to Burling and to emplusize his own fitness for the proposed mission submitted a memorandum of his answers to some thestions from Governor Herrera regarding the attitule of the Initerl States towarls Mexico. Wilkinson lonserel to obtain "some interestime appointment" which would emable him "lyy irreftagible evidence to strike dumb" his "slanderors and revilers." Probably this desire was strength"ned by the recent sugestion of the secoetary of war, made in comnection with an order to ascertain the fate of sone members of Pike's party, that the officer sent for this purpose should note thr general effect that recent erents in Europe lakl harl ou Mexico. Sinch evonts might produce results "highly intoresting to tho United States" and demand their. "strict attention.", "1. Thus influenced, Wilkinson composed a second lettru to llerrera covertly suggesting common action in belialf of sipansh-Ameriean imbependence. It the same time he did not menlect his pressomal aflairs, for he asked Herrera to disprove

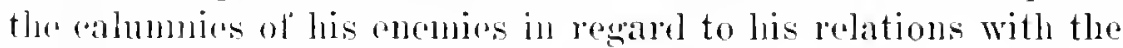

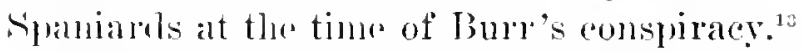

Farly in Tovember Wilkinson again assmed Foleh that the Fuanish-1muricans miglit comnt on the assistance of the United Nitates. Drspito newspaper reports to the contrary, ninety-nine ont of a lomeled of his fellow citizens felt the same. 'Theil own alfairs with Great Britain and with France were not in a flattering condition. The embargo was to contimue under sot greater restrictions. But he piously hoped that God would favor the

12 Seeretary of war to Wilkinson, September 8. 1808. Inelosed under date of Septemher 3, 1809. Manuscript in Letters Received, in war department.

13 Wilkinson to lferrera, Oetoluer 12, 180s. Jefferson Papers, ser. 3. vol. 85:103. 
cause of the just, in which number he inchded Folch's compatriots as well as his own.. ${ }^{14}$

Wilkinson's language nettleel Folch beeause of its prophecy if not its hypocrisy. In his reply he called the American's attention to the series of defeats that the Spanish people had recently inflicted upon the French armies, by virtne of whieh they might style themselves the Romans of the moder'n world. For this reason the United States shond value their friendship above that of any other power; but he failed to convinee the other. While the general still hoped, as erery good patriot should, that Hearen would favol "the magnanimous sons of the Peninsula," he feared that the combined armies of Alexander and of Bonaparte would prove irresistible. The colonial leaders shonld prepare for such an untoward event as the fall of the mother comntry. Should this ocenr Spanish-imerica, united, or'ganized, and in alliance with the United States, might bid defiance to all the warring nations of Europe. ${ }^{25}$ In this fashion the suspected Spanish pensioner assumes a Pan-Ameriean rôle that places his name among the earliest advocates of the Monroe Doctrine. We camot escape this conchusion nnless we prefer to believe that Jefferson inspired his ntterances, and this wonld imply an intimaey between them that was of little ceredit to Jeffer'son. In his letter to Folch, Wilkinson expressed the hope that if his prophecy came true, Folclu's "surpassing talents in political seience" wonld receive adequate recognition. This reiterated wish aroused Foleh's suspicion and led him to await with resentful cmriosity their fortheoming interview. This was to take place as a result of Wilkinson's recent orders to assemble in New Orleans "as large a body of troops as possible." ${ }_{16}$

With his usual desire to make an impression Wilkinson wrote Folch that his force was to number seven thousand. ${ }^{17}$ It was not this fact alone that alarmed the Spanish governor. His suspicions were already aroused by the muster of the Orleans militia in keeping with the new military policy of the American govermment. He believed that that govermment had sold itself to

14 Cf. n. 10.

$15 \mathrm{Cf}$. ก. 10.

13 Annals of Congress of the United Statcs, 11 Congress, 1 and 2 Session, $2: 2435$. 17 Cf. n. 10. 
France in return for a promise of the Floridas and Canada, and that Wilkinson's explanation was a mere pretext to lull him and his fellow officials into fancied seemity. Moreover Wilkinson wrote that lie bore a special mission from the president of the United states to Somernelos and to Foleh, and he asked the latter to secure for him a farorable reception at Harana.

The fact that Wilkinson was charged with a special mission to them aroused the apprehensions of both officials. Wilkinson's former position as a Spanish pensioner rendered him all the more dangerons. Folch feared that he might now employ in favor of tho United States all those measures that he had formerIy advised spain to use in curbing the former's territorial pretensions. Folch seemed to feel that his previons intimaey with Wilkinson might cast suspicion upon another interview between them. So he assured Someruelos that if any other than Wilkinson was to be the president's messenger, he should try to prerent lin from coming to Pensacola. But he knew the American weneral so well and had the key to so many of his secrets, that he thought he could gain from him more than anyone else. Wilkinson believed him to be his friend and he had so acted on several occasions. The Spaniard regarded the general as a sort of fel. low subject, who had snffered on account of his attachment to Spanish interests, but at the same time he claimed that the American lacked all qualities that conld recommend him as a private individual. ${ }^{\text {s }}$

In reply Someruelos warned Folch to be circumspect in dealing with "No. 13," with whom in less eritical times "His Majesty had some relations." ${ }_{19}$ He immerliately asked the Mexican viceroy, Garibay, to assist him in defending the Floridas. Vidal had already informed the same official of the projected rendezvous of the American troops. He had explained this on the ground that the American government hoped to gain the Floridas throngh French influence or at any rate keep Great Britain from occupying them. Vidal and Somemelos likewise learned this latest news regarding their "inquiet neighbors the AngloAmericans" from Foronda, the clarge representing the regency in the United States; and each in turn transmitted the new de-

18 Foleh to Someruelos, January 26, 1809. Reservado No. 130; ef. n. 10.

19 Someruelos to Foleh, February 28, 1809. Cuban Papers, Legajo 1566. 
tails to Mexico. Vidal also informed Folch of his latest advices and surmises." As a result of this double warming, frontier officials in the interior provinees of Mexico and in the Floridas prepared to make the best aramement of their slender resources to meet the anticipated peril. The ineident illustrates the completeness and intricaey of the Spanish system for transnitting information.

The hostile attitude of France and Great Britain furnished the pretext, if such were neederl, for assembling this foree in New Orleans. The govermment of the United States had already taken measures to increase its regular army and to mobilize the militia of the several states. Before the close of 1808 rumors became curent that a large British fleet had been ordered from Ilalifax to the West Indies. The American press affected to believe that it was destined for the Floridas, and that it might even attack New Orleans. These reports, with rumors of the revival ot Burr's conspiraey, and with reported British intrignes in Spanish-Ameriea, alamed the American government. In reporting to their home anthorities the Spanish and French representatives commented adversely upon these rumors and the consequent American precautions. Foronda asked the secretary of state to explain why the arministration planned to conrentrate four thonsand nem in New Orleans. He expeeted Madison to give an "oracular response" only to his inquiry. Turrean told his government that the English were demanding the privilege of navigating the Mississippi to Baton Rouge but that he had warned the Americans not to permit Great Britain to become their neighbor in the sonth as well as in Canada. ${ }^{21}$

In due time the Spanish comncil of the regency at Seville turned its attention to the new problem afforded by the alleged hostile movements. Its member's were persuaded that the United States was acting in accord witl France. Secret emissaries of the latter power were already working in their colomies. It was true that Wilkinson, the designated commander at New Orleans,

20 Vidal to Foleh, January 20,1809 . Cuban Pipers, Legajo 63. Vidal to Garihay, February 13, 1809. Estado, Legajo 5543, A. II. N. Someruelos to Garibay, February 12, 1809. Estado, Legajos 5543, 5550, A. H. N.

21 Foronda to eaptain-general of Cuba, January 6, 1809. Cuban Papers, Jegajo

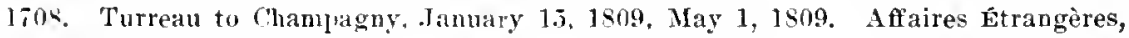
jitats-Unis, $62: 13,142$. 
had once heen a Spanish pensioner, but his recent part in Pike's experdition rendered him an object of snspicion. His ambition might lead him to excite insurrection in the Spanish provinces. Acting meler their instructions their representative in London, Juan Ruiz de Apodaca, reported this movement in the United States as new eridence that the enemy of miversal trancuility had bronght that power under his infmence. Camning instructed the new British minister, Franeis James Jackson, to make vigorous representations on the subject.22

In his dispatch, referred to above, Turrean charged that the new administration under Madison desired to gain the Floridas just as the preceding one had gained Lonisiana. Jeffer'son, indeed, had suggested this idea in a letter to Momroe, Jamnary 28 , 1809. He believed, though muwillingly, that Bonaparte wonld subdue Spain. This might lead him as well as Great Britain to relax their commercial exactions. With the mother country at his feet the conqueror wonld gaze longingly npon her colonies and try to purchase the neutrality of the United States by repealing her decrees and perhaps incheling the Floridas in the bargain. Monroe, however, did not believe that suceess in Spain and in her colonies wonld learl Napoleon to faror the United States in this mamner. ${ }^{23}$ The expression indicates that the presitlent was willing to profit in this way even while le was urging these colonies to exclude Napoleonic and British influence alike from this continent. But a few weeks later he wrote his friend Dupont de Nemours: "All these concerns I am now leaving to be settled by my friend, Mr. Madison." "24

Meanwhile the man who was largely responsible for the anxiety of the Spaniards embarked at Baltimore on Jamnary 24, 1809 , for New Orleans. He took with him fifty barrels of flom - an act which may have eaused his superiors some misgivings, for the embargo was still in force. Such minor points as this and his request for an extra allowance on his expense account caused public criticism and rendered him a less useful agent for

22 Apodaca to Canning. May 18, 1809. Publie Recorl Office, Foreign Office Reworls, Spain ser. 72, vol. 84. Apodaca to Garay, June 9, 1809. Fstado, No. 197, Legajo 5559.

23. Jefferson, Writings (Memorial ed.), 12:Q40; James Honroe, Writings (S. M. Hamilton ed. - New Fork, 1895-1903), 5:99.

24 Jefferson, Tritings (Memorial ed.), 1::\$59. 
the delieate mission before him. ${ }^{25}$ While at a public dimer at Norfolk he displayed his unfitness still more clearly, when he proposed the toast: "The New World, governed by itself and independent of the Old." Foronla promptly reported this to Somernelos as an additional reason for refusing him permission to land at Havana. Turreau carried his complaint directly to the department of state. Gallatin was instructed to tell him that the new administration must not be held responsible for Wilkinson's vagaries. ${ }^{26}$

The Ameriean government was sending Wilkinson to Harana without a passport from Foronda. The Spanish ehargé also warned the authorities against another of Jefferson's emissaries, "the assumed consul, Anderson." He hoped Someruelos wonld refuse to receive either and the eaptain-general wrote that he would do so. It was by eonduct of this same Anderson that Wilkinson informed Someruelos of his proposed risit to Harana, to confer "on subjects of interest to our respeetive governments." "2i Bad weather detained him at Charleston for some weeks; and during this delay here, as well as at other stopping places, he displayed a lively interest in such personal matters as his future career, the new head of the war department, and the latest "vindictive efforts" of "Randolph and the black mouthed federalists." In addition to his enemies in his rear he looked forward with some perturbation to meeting Daniel Clark at New Orleans. ${ }^{29}$

Wilkinson and his flour were conveyed from Charleston to Havana on the sloop of war Hornet which on Mareh 23 reached the Cuban port. Here he found a series of riots in progress against its French residents. So great was the resentment against all foreigners that his aide-de-camp experienced some difficulty in presenting a personal request for andience with the captain-general. Despite the latter's assuranee to Foronda, he formally reeeived the Ameriean general and his snite. Possibly some of Wilkinson's flour aided in bringing abont this conces-

${ }_{25}$ Report on General Tilkinson, 503, 545, 559, 563, 564. Cf. n. $\mathrm{S}$.

26 Foronda to captain-general of Cuba, January 20, 1809. Cuban Papers, Legajo 1708. Turreau to Champagny, June 1, 1809. Affaires Etrangères, États-Unis, 62:194.

27 Wilkinson to Someruelos, February 29. 1809. Cuban Papers, Legajo 1708.

28 Wilkinson to Dearborn, January 2,1809 ; Wilkinson to .Joln Sinith, chief clerk of the war department, March 12. 1809. Letters Received, war departuent. 
sion. On the twenty-sixth the general gave Somernelos an unsigned note which the latter answered on the thirtieth. Disturbanees within the city prevented further conferenees, and on April 2- Wilkinson contimed his voyage to New Orleans. Upon his departme Somernelos sent Garibay a new call for help which caused the officials of New Spain to renew their efforts at defense and adopt at their chief seaports a more intolerant attitude against foreign conmeree. ${ }^{29}$

What was there in Wilkinson's or rather Jefferson's commmication to Somernelos to produce snch a result? The missive begins by expressing sympathy for Spain in its strnggle for independent existence and regrets that the police regulations necessary to enforee the embargo had inconvenienced its "innoeent neighbors." This sugrestion of a difference between their attitude towards the colonies and the mother comtry is further emphasized by the statement that the United States cherished no antipathy against Spain and still less against "its immediat" neighbors in the Western Hemisphere.' In view of Wilkinson's later proposals to Vidal and to Folch we may regard this as designed to entice Somernelos into independent action; but the captain-general ignored it.

After this elaborate introdnction of marked friendliness there follows a statement that Wilkinson was to reinforce New Orleans for the sole purpose of protecting recognized American territory. The United States neither intended nor desired to nsurp any region occupied by Spain. For the present it wonld not even reopen its claim to West Florida. Bnt if an "inimical power" attempted to use that teritory" in attacking the American possessions on the Mississippi or to disembark troops in East Florida, then the United States wonld "regard itself as anthorized (withont any hostile view against Spain or its interests) by well known principles in time of war, and by Natural law and the law of Nations, to oppose such an attempt by all possible means; connteracting the designs of its enemies by such movements and seizures as cireumstances slonld dictate." Such was the message that Wilkinson was eluarged to deliver in th" "trne spirit of conciliation and good will." It will be observed

29 Someruelos to Garibay, April 7,1809 . Estarlo. Legajo 5543, A. H. X.; also Cuban Papers, Legajo 700 . 
that it closely follows Wilkinson's sngrestions to the president.

The eaptain-general's natural impulse was to ignore this conlbined temptation and threat. The recent warnings of Folch and of Foronda impelled lim to take the same conrse, and to inform his fellow officials of the impending danger. He answered Wilkinson that his missive suggested momentons diplomatie questions that only those "espeeially appointed for the purpose" could disenss. He mentioned the ruin that threatened most European peoples and warned against trusting the unnamed Corsican. He inelosed with his note a proclamation that he han lately used to arouse the people of Cuba. Thus he foiled Wilkinson's attempt either to seduee or to frighten him. The Amer'ican general nust then direct his efforts towarels his whilon friends, Folelı and Vidal.

The former was not in Pensacola when Wilkinson reached that port, for he had alreaty transported himself to Baton Rouge, the anticipated seene of danger, just as he had done under similar eircumstanees in 1804 and in 1807 . From the mouth of the Mississippi the general informed the new seeretary of war that "the awfully critieal situation of Spanish-Ameriea imperiously enjoins it on us to strengthen this feeble, remote and exposed quarter." He may have felt that Great Britain's forees in the West Indies constituted a serions menace, for he offererl to seizc West Florida before that power could do so. Perliaps he was not sure of the new administration's attitude despite what hre had just told someruelos. He suggested that this seizure might "affect Cuba and Mexico to our injury." " He may have feared that either Great Britain would then oeenpy Cuba or the Mexiean authorities rejeet the proffered American allianee.

While Wilkinson was journeying towards New Orleans affairs in that city were shaping themselves to promote his mission. On Mareh 19, Claiborne wrote the secretary of state that two officers, whom he regarded as Foleh's per'sonal representatives, had expressed their opinion that their eonntry must shortly yield to Bonaparte. Thereupon the Spanish possessions would declare their independence. In that event they wished to know if the American govermment wonld reeeive a minister from Mexico? Claiborne guardedly replied that while he had no in-

3o James Wilkinson, Memoirs of My Oun Times (Philadelplia, 1816), 2:344.848. 
structions to guide him, he thought the Lnited states wonld gladly do so. His informants then stated that a certain Renelon had aheady been designated to represent Mexico in the United States, and a Spaniard of Irish extraetion, Murphy ly name, in Great Britain. These offices's also intimated that moler the new regime East and West Florida might be cenderl to the United States, and they represented this as Folch's own view. ${ }^{31}$ It certainly differs from the sentiment expressed in his comments on Wilkinson's previous snggestions, but the wily Spaniard may. have used this method to aseertain Claibone's position on this and kindeel topies. It might lead the Americans to take the initiative, when the conclitions grew so bad that he conld no long"l hold his provinee, and thus relieve him of a certain responsibility to his own govermment. On the other hand Claiborne evidently wished to aroid committing himself "ren to the extent that Jefterson's letter of the previous October justifind him in going.

The president evidently wished to be sme that the spaniards learned of his intentions, for shortly after this interview Claiborne received from him instructions similar to those given Wilkinson. In this propaganda therofore the two men were to be closely associated, but the Orleans executive was not wholly in the dark as to the aims of his colleague as he had been on former oecasions. This promised more benefit to the nation, if not to the latter's devious schemes. He therefore broached the matter to Vidal, the Spanish vice eonsul, who had ahearly noted the arrival of American recruits in New Orleans. Viilal also knew that Wilkinson intended to call on Folch and foncruelos while on his way to that plaee. For some time he harl tried in vain to learn the reason for these movements. In the latter part of Mareh Claiborne called on him, in aecordance with .Jefferson's instruetions, and readily explained the mystery."

The American executive assured Vidal that his goremment chorished tho ntmost good will for Spain and its colonios, despite discreditable reports to the contrary, and wished for the

31 Personal letter of Claiborne to seeretary of state, March 19, 1509. Manuseript in Claborne parkage in bureau of rolls and library. D. W. Parker, Calendar of Papers in Washington Archives Relating to the Territories of the Inited States (Washington, 1911), no, 7560.

32 Vidal to Garibay, April 10, 1909. Marina, 1809-1814. ef. n. 9. 
mother comtry a happy ontcome in its struggle against the "Tyrant of Europe." If, mhappily, the result should be otherwise, his snperiors were ready to aid the eolonies in every possible way, provided they preferred the rule of Ferdinand VII or of any other government than France. The president believed that the United States conld do this withont coopperating with "any other nation holding similar views." For this purpose it was ready to declare war against France and constitute it selt the protector and ally of those colonies that were unwilling to follow the fate of the metropolis. If they desired to send an envoy to treat with his government, he wonld meet with a friendly reception and obtain marked favors for his constituents.

The vice consul thanked Claiborne for his friendly sentiments, but adled that his government had not anthorized him to discnss such delicate matters. Personally he believed that the Spanish eolonies would never sulmit to a foreign power, nor forget their allegiance to Ferdinand VII or his heirs. Like the people of Old Spain too, those of New Spain were not ummindful of Great Britain's efforts in their behalf. The suggestion that that power must be included in the proposed diplomatic mdertaking was not lost on the Ameriean representative. On the whole Vidal was much more circumspect in his attitude than Folch, although we must remember that he was making his own report, while Claiborne is narrating the statements of unofficial intermediaries. Yet Claiborne's later report based on a personal interview was of the same tenor.

In April the Orleans executive was at Pointe Coupée, opposite Baton Ronge; Folch was then at the latter place and immediately invited the other to dine with him. The governor is our only authority for what took place, for Folch himself evidently did not report this interview to Somernelos; yet we may be certain that he represents the Spaniard's professed views.

Foleh thonght that Spain still had a chance to oppose Bonaparte. In any event the colonies, especially Cuba and Mexico, would never recognize a dynasty that he supported, but upon the first intimation of Spain's fall, wonld proclaim their independence. Folch also professed to believe that the Floridas must ineritably pass into the possession of the United States, for they were of value only to that power. His offer to deliver to it his 
own province a year and a half later is in keeping with this alleged opinion. Folch also expressed the resentment that the regency felt over the report that Joseph Bonaparte proposed to eede the Floridas to the Luited States. He suggested that his nation wished to cultivate friendly relations with the latter and hal apprised Great Britain of this fact. He may have wished to intimate that the Initen States would profit more from the combined friendship of those two peoples than from its former sulsserviency to France.

In reply Claibormo stated that his country was intensely interested in sivain's strugers for inclependence, but its policy was not to interfere dircetly in European affairs. If Spain should be successful, the United States would acquiesce in luel lomination of Cuba and Mexico, but would reguet to soo them under the political or commeresal control ojther of Great Britain or of France. These expressions ame in hamony with those of Wil. kinson and so elosely follow lefferson's previous sugegestions that one need not seek further to find theris anthor: ${ }^{23}$

Folch, like Vielal, mentionmel sipain's foreling of gratitucle towards Gleat Butain, thus indicating that this sontiment harl a common origin. But he did not think that that power womld ever gain possession of the spanish colonies. We armitted that Mexico and cuba would need a foreign allianee to maintain their independence, and woulel probably approach both Great Britain and the Unitel states on this sulject, but preferably the latter. Claibone mentioned the desire to exclue from this continent all European and paticulary British and Frencl influence as a guarantee that in thrir struggle for independence Mexico and Cuba might rely alssolutely on the forcudship of his rountry. Ho assured the of her that these were his private views only, but they follow Jaffreson's letter alunost verbatiun. Possibly he desired to rival the West Florida governor in finesse. Doubtless he was enatified when later at dimurer Folch wave as his toast: "The liberty of the New World; may it never be assailed with suceess by tle old World." Possibly Folch knew of Wilkinson's similar toast at Norfolk and was helisively paraphrasing it for his guest's henefit. 'Ihe latter reporterl that the

33 Personal letter of chaborne to Smith, April 21, 1809. I'arker, Calemar of Papers, no. 7567. 
assembled eompany, largely composed of Spanish offieials, received the toast with favor.

If, in New Orleans and Baton Ronge, Great Britain seemerd the chief obstacle to a Pan-American alliance, France appeared in a similar light to the administration. Evidently Jefferson's books and his farm did not wholly suffice to occupy his attention in retirement, for, on April 19, he wrote to his successor: "I suppose the conquest of Suain will soon force a delicate question on you as to the Floridas and Cuba, which will offer themselves to you. Napoleon will certainly give his consent withont difficulty to our receiving the Floridas, and with some difficnlty possibly Cuba." Eight days later he added: "Napoleon ought to conciliate our good will becanse we can be an obstacle to the new career opening to him in the Spanish colonies.' The Floridas alone would not be a sufficient reward for American nentrality. Our govermment wonld acquire them anyhow at the first outbreak of war and until then dicl not need them. Napoleon must also agree to the American acquisition of Cuba, if he wished a free hand in Mexico and the remaining colonies. ${ }^{3+}$ This implied doubt in regard to the ontcome of Wilkinson's mission and a desire to seemre American interests in any event. He wrote W. C. Nicholas that, in case Napoleon continued his commercial exactions, the people of Cuba and the Floridas might proffer themselves to the United States.

The situation had greatly changed since the preceding autumn. Then neither France nor Great Britain showed any disposition to compose its differenees with the United States. Now Madison thonght that the former was inclined to be more conciliatory. If, then, Napoleon shonld attempt to keep the United States from trading with the Spanish colonies, as it had formerly done with Santo Domingo, and should couple this requisition with an offer to cede the Floridas, it "wonld present a dilemma not very pleasant." ${ }^{35}$ Evidently his ambition was not so great as his predecessor's who wished to mark our territorial pretensions to the sontlwward by a column on the farther shore of Cuba. In . Jefl'cr'son's view we conld dofend this region withont a uavy and this factor shonld determine our rule for expansion.

34, Jefferson, Writings (Memorial ed.), 10:273, 277.

$3 \pi$ James Madison, Writings (f. Hunt ed. - New York, 1900-1910), 8:53. 
Turrean hanl already presented the umpleasant "dilemma" that Marlison formert. Incensed at the repeal of the embargo, which, unaceompanied by a deelaration of war, he regarded as a mo-British measure, he now demanded from the new administration an explanation of some other current rumors. One referres to a general projuct to revolutionize Spanish-Ameriea. Another speeifically charged the American govermment with in"iting secret assemblies in the Floridas, patterned after those that Miranda had orgmized in Caracas, and eneouraging similar measures in Cuba. Finally the anxiety in regard to the British Heet at llalifax was simply a pretext to justify the coneentration of troops at New Mrleans. The French minister professed to heliove that these reports were cirenlated by those who wished to sever the harmony existing botween his nation and the United states, rut he had reported them to his conrt and awaited with interest an explicit answer from the Aneriean anthorities. ${ }^{36}$

The president had already written to .Jefferson: "Cuba will, without doubt, bo a cardinal object with Napoleon." Conld he liave seen Turrean's dispateh to Champagny of April ⒉2, 1809, ho wonld have bern confirmed in this view and donbtful of the immediate futmre. The Freneh minister elaimed that the conrentration of American troops in New Orleans under Wilkinson arose from a desire to coopperate with the independent party in the Floridas, rather than to dofend that eity against possible British attack. Wilkinson's visit to Havana gave point to an anonymons charge, which he attributed to a clerk in the state department, that the United States was sending revolutionary agents to Mexico, the Floridas, and Cuba. Turrean suggested that his govermment should use the riots in Cnba that had interfered with Wilkinson's mission as a pretext for the immediate soizure of that islant. Having thus forestalled the Americans there, the French might later oceupy the Floridas and Mexico. ${ }^{37}$

After submitting his pointed inquiries of April 15, Turreau withdrew in a rage to Baltimore. Madison desired to avoid rupture with France and requested Gallatin to call on her minister on his way northward and explain the real sentiments of the administration. Evidently Gallatin believed that the presi-

36 Affaires Ftrangeres, Ftats [nis, 62:133.

37 Affuires Etrangères, Etats. Lnis, $62: 1: 1,1: 3$. 
dent's views were the same as lis own; otherwise, it will be lifficult to reconcile Turreau's report of them, if correctly given, with Madison's later action.

Gallatin told the French minister that the administration disclaimed all responsibility for Wilkinson's ntterance such as the Norfolk toast. This was to be attributed to "the vanity, the indiseretion and the ordinary ineonsistencies of that General," whom the other knew as well as they. If 'Turrean imagined that Mr. Madison desired the Floridas, he was mistaken. That was Mr. Jefferson's hobby, but diel not lepresent the views of lii. cabinet. The Floridas would be desirable only because their possession might prevent misunderstandings with Spain and secure an ontlet for the sonthern states. The administration was in no way responsille for such popular mectings as had taken place there, and they had heard nothing in regard to Wilkinson: reception by the Spaniards. Is for Cuba, the United States would not take it as a gift. ${ }^{38}$

Gallatin's assurances evidently failed to convince the other. In reporting them Tureau called his superior's attention to the fact that they were accompanied by no farorable action in regard to a commercial policy. At the same time Secretary Smith instructed Armstrong at Paris to say that while it was the general poliey of the United States to preserve neutrality towards the Spanish colonies, they would feel free to act otherwise, if necessary to preserve their territorial claims. ${ }^{39}$ When the Erskine agreement resulted in a fiasco, Jefferson wrote Madison that if Bonaparte were wise enough to change lis attitude toward the United States he must inevitably lead it to declare war against England. In that event he advised the immediate ocenpation of Baton Rouge in order to forestall the British. Om claim to this territory wonld justify the step."

The inconsistencies of Jefferson's and Marlison's commercial policy thus characterize their attitude towards Spanish-America and even the neighboring West Florida. Jefferson was reary to assist a revolt in the Spanish colonies, shonld Bonaparte dom-

3s Adams, History of the Vniled Stales, $5: 37,38$.

39 Smith to Armstrong, May 8, 1809 . Instructions, vol. 7 , manuserilt in burealu of indexes and arehires.

40 Jefierson, Writings (Nemorial ed.), I2:304. 
inate Spain. For this le expected the Floridas as his reward. Hence, his clesire to open diplomatic relations with them, even through the untrustworthy Wilkinson. At the same time if Bonaparte should pursue a more favorable eommereial policy towards us, he might purchase our nentrality in respect to his own Spanish-American plans, by the lrike of the same Floridas witl ('uba inchuder. His own calbinet dis not seem to approve his riews, but he persisted in setting them on foot, and eren exerted pressure on his successor to continue them. On assuming office, the latter promptly repuliated them, hut ere his first administration was half completed, le was exerting powerful efforts to sain both the Floridas, and at the same time trueklingr to Bonaparte.

Meanwhile the meonseions if not innocent object of so mueh report and conjecture reached New Orleans. His long delayed arrival represents a distinet anticlimax to what might have proved an interesting diplomatie rpisorle. Wilkinson's interriews with his former friends Virlal and Folel were as fruitless as his brief visit to Havana. To the former lo immediately reported the substanee of his eommunication to Captain-General Somernelos. This dirl not differ' materially from what Claiborne had already tohl the vier consul abont the proposed PanAmeriean alliance. In reply Virlal repeated what he had previonsly said to the governor - that Spanish-Ameriea would probably follow the lead of the mother eountry and preserve friendly relations with Great Britain. Conserpently any hostility between that power and the Lnited states might be an obstache to the proposed Pan-Amrican allianee.

Wilkinson elained to represent the sentiments of the administration and now tolel Vidal that he expected his country and Great Britain to compose their differences and deelare war against France. In that ease there would be no objection to inchding Great Britain in the proposed allianee. He may have had some intimation of the Erskine correspondence upon which to base his assertion. Virlal was inelined to believe that Wilkinson correctly reporterl the attitude of his govermment, for unless the British nation was a party to the suggested alliance, the Enited States would be more than ever exposed to European 
machinations. Tet le felt that the western world as a whole was reasonably safe from European invasion. He even suggested that the death of the tyrant or some other accident might alford the mited and grateful Spanish colonies an opportunity to reseue the mother comtry from eaptivity. ${ }^{* 1}$

We have as yet no complete evidence that Jefterson instructed Wilkinson to propose a Pan-American alliance to the Spanish officials that he visited. His cabinet had tentatively suggested such a policy before he ordered Wilkinson to New Orleans. That general had more than hinted at it and was only too anxious to receive instructions to carry it ont. His communications to Someruelos suggest that he had them in reserve but the riots in Havana and the eaptain-general's attitude gave him no chance to present them. The case was otlierwise in New Orleans where lis former friends not only gave him the opportunity but even partly suggested the subjeet matter of his discourse.

It is likewise possible that Wilkinson first definitely heard of the proposed alliance from Vilal and Claiborne, after his arrival in New Orleans. Owing to the lack of discipline among his troops and the havoe already wrought by disease it would be a useless proceeding to assure the Spanish authorities that they had nothing to apprehend from the military forces in New Orleans. They already knew that for themselves. On the other hand the eondition of these forces afforded his enemies another opportunity to attack him, and they quickly took advantage of it. Accordingly he must employ every possible means to strengthen his tottering influence. He attacked his enemies for seeking to disconrage enlistments or to persuade his officers to resign. He appealed to the Spaniards in the interior provinces for additional testimony in his faror. At the same time he suggested to the administration a comprehensive plan for immediately oceupying West Florida and defending New Orleans. In his extremity the suggested alliance offered still another possibility of redeeming himself. He was fully instructed to interview Folch on another subject. He would add to it the proposed alliance, appeal to their former friendship, tempt the governor's personal ambition, and lead him to place himself at the head of this

41 Inclosure no. 2 in letter of Vidal to Garibay, April 10, 1809. Cf. n. 32. 
new movement. Vidal had suggested the necessity of inelnding Great Britain in this alliance, and although without definite instruetions on this point, he ineorporated it in his proposal. By this means he wonld inangurate a deservedly popular movement, in the glory of which he might he safe from his most persistent foes.

In pursuit of this plan, therefore, Wilkinson met Foleh at the San Juan brirge, April 28, and condueted him in a carriage to the government honse in New Orleans. In the comso of their ride together, as he tells us in two separate accounts, they conversed on the fate of Spain and the future interests of her colonies. IIr reported that Folch fully expected Bonaparte to triumph over Spain, but before that event he hoped the junta woukd direet him to deliver West Florida to the Tnited states. Mexico must then seck to preserve her independence either by joining the Cnited States or forming a confederation of her own. This is in keeping with Claiborne's previons report of the governor's attitude. Perhaps Wilkinson used this to fabricate the whole interview, or else Foleh was playing with him as he had with the Orleans executive.

When Folch mentioned the possibility of a Spanish-Ameriean confederation, Wilkinson remarked that to it the Floridas wond form a "feeble and pernicions appendage." Foleh assenter? and stated in case the junta did not act as he hoped, he wonld apply to the viceroy of Mexico for power to surrenter Wrest Florida; failing in that, to the president limself. Ho declareel that Great Britain should never get the provinee, for it was "as necessary to the United States as the drawer is to the case." The astonished Wilkinson observed that "the subject presented a solid ground of Conciliation and mutual confidenee," between their countries, which he wonld gladly promote. Folch dectared that he had never before uttered this idra, but it follows so closely his interview with Claiborne in Baton Ronge that one is tempted still more to regard that as the real sonrce of Wilkinson's reports. The general closes by alvising his superiors to send an agent immediately to confer with Foleh on the surrender of his province, ${ }^{42}$ which he suggested might be hastened by "an

42 J. W. to Madison, May I, 1509. Calendar of the Correspondence of James 
indemnity" to its officials. This was a natural but sinister suggestion in view of the charges already pending against the general.

If we are inclined to regard as gennine this report of the interview between Wilkinson and Folch, we may find evidence to corroborate it in Claiborne's contemporary correspondenee. The latter wrote that while Folclu was in New Orleans he freely expressed himself as favoring the independence of Spanish-Aneriea. He also convered the impression that most of his fellow officials entertained the same riews. Claiborme, however, doubted if the people were prepared for such a step. They were "deplorably igmorant, musually superstitions, for the most part poor, indolent and easily controlled by their priests." Any attempt on their part at self govermment, therefore, would be foslowed by "scenes affecting to humanity." The anarehy then prevailing in Harana suggested the possibility of reënarting there another Santo Domingo.

Claiborne thought that neither Mexico nor Cuba single handed conld long maintain its independence. With the people soon losing their enthusiasm it would be impossible to keep then: out of the clutches of France or Great Britain. In such a contingency the latter might demand a commereial monopoly as its reward and this course would prove as injurious as the rule of Joseph Bonaparte. Claiborne felt that it would be impossible to maintain much longer the policy of nentrality that the United States had hitherto observed between the rival factions in Spain. "The interest of the Uniter States requires that all Emropean inflnence shonld be banished from the continent of America," he echoed, and "the present crisis is favorable to the accomplishment of so desirable an object." We closed by stating that he forebore to advise the govermment further. ${ }^{43}$ It was well that he did so, for he was simply paraphrasing Jefferson's missive of the preceding October.

Foleh's own letters to his superiors are filled with strong expression of loyalty to Ferdinand VII, and lie offered to serve

Madison (Washington, 1894-1895), 726; also 38 Miscellaneons Letters, filed unler date of January 1, 1813, in burean of indexes and archives.

43 Claiborne to Smith, May 14, 1809. Claiborne Correspondence, 5. Parker, Calcudar of Papers, no. 7567. 
Spain against the invader. These letters and his own subsequent course certainly show him in no sense as a champion of spanish-American independence. Yet it is probable that the reports of Wilkinson and Claiborne in l'ear to his willingness to deliver West Florida may have some foundation, for a year and a half later he actually made such an offer. It is likely, too, that when his offer came, the atministration conceived extravagant hopes from it based on his earlier conversations with these American officials. On the other hand it is equally likely that, while conferring with then, the Spaniard knowingly conveyed more than his real views. He despised Claiborne and distrusted Wilkinson, and may have thought himself justified in deceiving them and the government they represented. From it, if not from its immediate agents, he apprehended the most immediate peril to his dominions.

So far as his letters from New Orleans are concerned, one might infer that Wilkinson's mission was simply to reassule him upon this point. The general delivered to him a communication similar to the one already given Somernelos, to explain the assembling of American troops at New Orleans. Folcli arlmitted that this movement had caused him some anxiety, appleciated the good intentions of the Uniter States, and assured Wilkinson that his own were friendly." When, however, Foleh returned to Pensacola, lie unbosomed himself to his superior. His letter on this occasion clearly shows that Wilkinson's elaborate explanation of the presence of troops in New Orleans was largely a pretext suggested hy Jefferson to conceal their real purpose - the opening of diplomatic relations with the Spanish colonies.

Wilkinson triek to show Folel, so the latter wrote, that Spain was bound to succumb to Bonaparte. Accorting to Claiborne's leport the Spanish governor alleady believed this, but he obviously did not wish his superiol to think so. In such an event it would be highly desirable to form an alliance to include Spanish-1merica, Brazil, the United States, and, if necessary, England. 'The adelition of the last-named power' was probably an

44 Wilkinson to Folch. May 3, 1809; Foldh to Wilkinson, May 4, 1809. J. A. Robertson, List of Documents in Spanish Archives. . . of Which Transcripts are Preserved in American Libruries (Washington, 1910). nos. $5168,5169$. 
after-thought inspired by the interviews with Vidal, or by preliminary information in regard to the abortive Erskine convention. In case the Spanish colonies declared their independence, it would be desirable for them to have an agent near the United States, and Folch himself would most acceptably fill that offict because he knew so thoroughly all the factors involved. This additional evidence afforded by Wilkinson's interview with the Spanish governor serves as a link in Jefferson's policy and explains the general's correspondence of the preceding antumn.

Folch told Wilkinson, so he wrote Someruelos, ${ }^{45}$ that while he felt flattered at this expression of conficlence in himself, he thought that children onght not to be in haste to divide a parent's property before her death. Furthermore he liad no intention of beginning a policy that he conld not carry through. Believing that both Wilkinson and Claiborne represented the ideas of their govermment, he pointed out to his snperior that the proposed alliance might serve to rescne the mother country from Bonaparte. Possibly he desired thus to protect himself, should any report of his views as given to Claibome or to Wilkinson chance to reach Someruelos. Folch assured the latter that America, well governed and united, wonld be inacessible to Bonaparte. Should his ambitions tempt him, the royage wonld mark the beginning of his overthrow and the climate, its end. The Corsican, however, wonld hardly ventmre to repeat on so extensive a scale his experience in Santo Domingo, yet the governor assured the captain general that he was ready to act against him as Somernelos might desire.

In communicating Folch's dispatches to his superior's, Someruelos observed that he was mable to appreciate Folch's conrersations with Claiborne and with Wrilkinson, for that official had not reported them in sufficient detail. He adrised the gorernor to remedy his reports in that respect. He also expressed his surprise that Folch had rentured to discuss snch delicate subjects and advised him to shm this con'se in the future, for the Americans simply desired to draw out the riews of the Spaniards and later turn them to their advantage. The miform reply to suggestions for independence and alliance shonld be that

45 Folch to Someruelos, May 23, 1809. Robertson, List of Documents, no. 5170. 
the Spaniards would die to preserve the union of the two Amerjeas with Spain."

Despite the firmmess of tone that Someruelos assumed towards lis superiors, or that Foleh employed with him, there is a sugarstion that rach believed that a sperdy catastrophe was ineritable, but wisled to shield himself from any responsibility for it. Foleh also attempted to play off Claiborne against Wilkinson in an endeavor to ascertain if both correctly reported the attitude of their superiors, while Virlal evidently worked with him to the same ent. It the same time Folch expressed himsolf so as to arouse Amrrican hopes in regard to the Floridas and establish his influence with their officials in case he had to lely mpon them in an extremity. In this way in the crisis of 1810-1811, he managed through the American authorities to proserve Mobile trom a filibustering expedition, and at the same time remained in good standing with his superiors. Such was the influence of the Florida question that it led American and sipanish officials alike to adopt a shifting course of duplicity.

That this influence was marked in the case of Wilkinson is hown by his communication of May 12 to the secretary of war. Folch was still in the city and his own any disorganized, but lye suggested an elaborate plan to defend the region, of which West Florida constituted the danger point. A week later, after the spanish governor had left New Orleans but before he had reached Pensacola, Wilkinson reported that a "commotion", threatener to break out in that city. Folch was likely to call upon him for assistance. He might be overthrown either "by the usurpation of the Spanish subjects or by the enterprise of the American settlers." In view of possible public advantage le wished to receive instructions at the carliest possible moment. ${ }^{48}$ In reply the secretary of war wrote him, July 2.2, 1809: "It is the continued wish and instruction of the president that no interference of any kind in the affairs and territories of Spain should take place, or be enconraged, or permitted, by any person or persons, whether civil or military belonging to or under the

16 Someruelos to G. F. O., Octoler 8, 1509. Cuban Papers, Legajo 157.

4 Wilkinson, Memoirs, 2:351.

48 Ibid., $9: 357$. 
anthority of the United States." ${ }_{49}$ Evidently the protests of the Frencl minister were beginning to affect the administration, although Canning's repudiation of the Erskine agreement contributed to the same end and warned it not to complicate its foreign policy further. Thus enderl the first effort of the Uniterl States to initiate a Pan-Amerien policy. Jefferson, in retirement, conld not force his snceessor to contime his mistaken poliey, nor support his murorthy protegée. The latter was obliged to resign his command and come northward in an nuavailing attempt to clear limself from charges of inefficiency as well as of personal corruption.

IsaA .JOSLIN COX

\section{University of Cincinnati}

49 Wilkinson to N. Salcedo, August 31, 1809. MSS. Internas Provineias Internas, vol. 239 , Expediente 2, 1. 39, Archivo General, Mrexico. 
P D $\therefore \therefore$ 




Hot

10

(4)

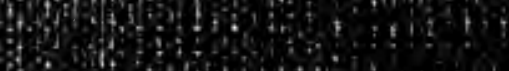

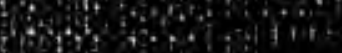

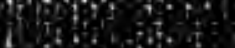

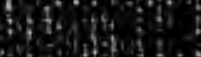

ift:

an?

.

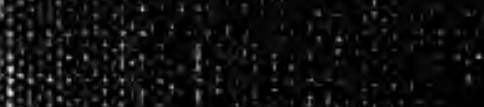

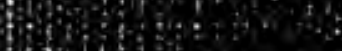

19

$+i$

i

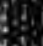

1.

is

28

$\frac{1}{4}$

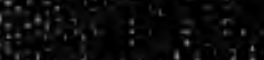

itition

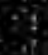

3

S. $5 .+1$

i.

itis

$1 \%$

1:

$\because$

$1, \ldots:$

$1+2$

$-67^{-1}=$

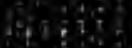

